\title{
ECO-INNOVATION AS A PILLAR FOR SUSTAINABLE DEVELOPMENT OF CIRCULAR ECONOMY
}

\author{
Jelena STANKEVIČIENĖ (10*, Marta NIKANOROVA (ib \\ Financial Engineering Department, Faculty of Business Management, \\ Vilnius Gediminas Technical University, Vilnius, Lithuania
}

Received 15 June 2020; accepted 23 June 2020

\begin{abstract}
Circular economy (CE) is based on environmental, economic and social dimensions which aim to ensure sustainable development on each step of product creation, transformation and conversion by creating a closed-loop economy. The purpose of the article is to propose a concept of measurement the development of eco-innovations in the context of circular economy, apply and provide empirical evidence based on the data of Baltic Sea Region countries. The study augmented for the models that include the analysis of the circular economy concept, the importance of eco-innovation in the context of circular economy including the accent on recycling, circular material usage, material efficiency and waste management. The multi-criteria decision methods MULTIMOORA and TOPSIS were used to assess the eco-innovation as a pillar of circular economy. Results are useful to add to theoretical building and also evaluate the socio-economic aspect in the concept of circular economy.
\end{abstract}

Keywords: circular economy, sustainable development, eco-innovation, MULTIMOORA, TOPSIS.

JEL Classification: D7, O11, O44, O52.

\section{Introduction}

The linear economy model exists already many years and up to the end of the 20th century perfectly met all the requirements for producers and for consumers. However, during these years life has changed, as changed the planet and resources (according to this model), producers and consumers behaviour, technologies, etc. Due to economic and technological development appeared new necessities, possibilities and new economic models to meet all these needs. Linear economy model using "take-make-dispose" approach is no longer able to meet all the needs - due to economic and technological developments the volume of production and consumption increased a lot, and the number available resources are drastically decreasing. Moreover, a huge volume of production affects the environment negatively by pollution of water, air, land, etc. The waste is not being eliminated enough that causing the additional issue. Economic models based on sustainability approach would be helpful to develop the economy and protect the environment at the same time. Circular economy is the model based on economic, environmental and social dimensions works as a closed-loop of resource movement from the primary extraction until the final consumption of the product. The main idea of circular economy is to turn the waste into the resource which can be used again at any stage of production or utilized thoroughly. The circular economy model changes not the only economy model, but as well the values, habits and behaviour of the consumers and producers, new business models, laws, etc. The shift from linear economy to circular economy has many barriers: finances, social aspects, jurisdiction, politics, development of environmentally friendly technologies and innovations. Eco-innovations are the critical element towards the shift to circular economy, as at the moment, there is a lack of technologies and possibilities to ensure zero waste at any stage of the production and consumption of the products, as well lack of recycling and reuse possibilities of materials. Eco-innovations are not only ensuring a switch to circular economy, but as well play a significant role in the protection of the environment, increase the efficiency of production and helps to build new environmentally friendly consumption behaviour.

${ }^{*}$ Corresponding author. E-mail: jelena.stankeviciene@vgtu.lt 


\section{The replacement of linear economy by circular economy}

Linear economy model which is widely used until nowadays in all over the world offers well-known "take-makewaste" concept when the natural resources are being extracted by producers to produce a product which turns into the waste after consumption. In the future, the economy may be at risk, as nowadays it is dependent on resources. While production and consumption each decade are rapidly growing, the shortage of resources will grow as well, what would cause a negative impact on the environment, society and economy itself. The circular economy model can solve this issue by allocation and protection of the resources. The circular economy approach aims to recover resources, economies and social capital. According to this model, which can be represented as a closed-loop, waste which is gained after the consumption of a product should be turned again into the resource and returned to the production of recycled without residual (Figure 1).

The linear economy is represented as the open-ended model (Figure 1), where the last process is the generation of waste after production or consumption. The linear economy turns into a circular economy when waste is generating resource after recycling (Saraiva et al., 2018). Waste can consist of biological and technological materials. Biological materials can be recycled and return to the environment without harm or returned to production. Technological materials are being reused or recycled without harm to the environment (Grigoryan \& Borodavkina, 2017). However, in some cases, there still be a per cent of non-recyclable waste which cannot be reused due to physical laws (De Almeida \& Borsato, 2019). Also, a vital resource is an energy, which demand is growing rapidly, cannot be wasted - it should be converted or dissipated (Tseng et al., 2018). Moreover, green innovation can improve organizational processes as well as products, which lead to economic and environmental performance
(Shafique et al., 2017) and provide the economic and environmental benefits from which businesses can profit following the introduction of eco-innovations (Hroncova Vicianova et al., 2017). Overall, non-recyclable waste should be a rare issue and should appear only if this is under the law of nature.

The circular economy model, differently as a linear economy model, includes recycling, material reuse processes and efficient resource use which lead to the development of eco-innovations and technologies, creation of jobs, increase "green" investment, changes habits of the society and contributes to the sustainable economic growth (Lahti et al., 2018). In other words, the circular economy is operating as a natural ecosystem, if there is a natural waste - it could be returned to the environment. However, all the materials what can be recycled and disposed of should be recycled and disposed to achieve "zero waste" target what is one of the key points of circular economy.

\subsection{Support of circular economy in the EU}

The idea of sustainable development in recent decades is popular not only among researchers but also among industry, business, policymakers. The sustainable development is being promoted using three-dimensional pillars - economic, social and environmental - affecting the environment, economy and society. The principle of sustainable development is to meet the needs of present and ensure possibility for future generations to meet their needs by saving environment and resources (WCED, 1987). Due to the growth of population, highly increased production and consumption, uncontrolled waste, economic growth, scarcity of resources, climate change and many other reasons - it is necessary to take an action in order to keep economic growth and at the same time protect environment, reduce harmful waste and safe resources.

The circular economy act as a model or tool by which sustainable development can be ensured. The circular

Linear economy model

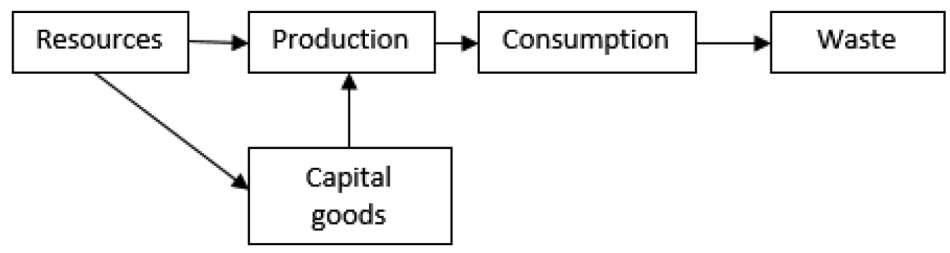

Circular economy model

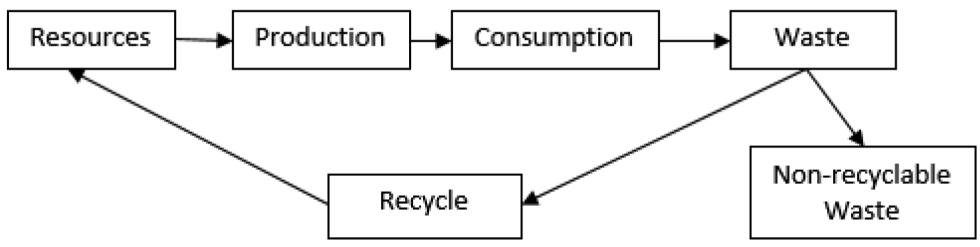

Figure 1. Comparison of linear economy and circular economy processes (source: adapted from C. Busu \& M. Busu, 2018) 
economy can be described as interdisciplinary model including environmental, engineering, social and economic sciences together with social aspects of ethics, justice, common environmentally-friendly norms, values and mindset. The sustainable development, as a concept, was presented in the UN Agenda for Sustainable Development in 2015 (UN, 2015), which is known as Agenda 2030. The Agenda presents 17 sustainable development goals and 169 targets. European Commission in 2010 launched a strategy for smart, sustainable and inclusive growth called "Europe 2020" (European Commission, 2010). It was the first document promoting the circular economy by highlighting the importance of sustainable enterprise and sustainable innovations. In 2013 European Commission issued Environment Action Programme (European Commission, 2013) which provides the principles of circular economy:

1. Eco-innovations are acting as a key to prosperity and a healthy environment;

2. Generated waste is equal to zero or can be reused, recycled or makes a minimum impact which cannot be disposed of doing to the physical laws;

3. Natural resources are being used efficiently, and biodiversity is protected, restored and valued;

4. Pollution and carbon growth is being sustainably managed.

The United Nations Conference on Sustainable Development in 2012 adopted the 10-Year Framework of Programmes on Sustainable Consumption and Production Patterns (High-Level Political Forum On Sustainable Development, 2012). Furthermore, in 2018 European Commission issued an agenda ensuring the promotion, support and spread of eco-innovations called "Innovation Union" (European Environment Agency, 2018) which corresponds to the goals of circular economy. In $2015 \mathrm{Eu}-$ ropean Commission presented Circular Economy Action Plan (European Commission, 2015), which is based on efficient use of resources, eco-innovations, sustainable use of materials, promoting ecological production and socially responsible enterprises, promoting "green" consumption and managing waste:

1. A common EU target for recycling $65 \%$ of municipal waste by 2035 ;

2. A common EU target for recycling $70 \%$ of packaging waste by 2030 ;

3. There are also recycling targets for specific packaging materials:

- Paper and cardboard: 85\%;

- Ferrous metals: $80 \%$;

- Aluminium: 60\%;

- Glass: 75\%;

- Plastic: 55\%;

- Wood: 30\%.

The Circular Economy Action Plan covers all the stages of product life-cycle - from its production to its consumption and waste management by implementing a market for secondary raw materials. The Circular Economy Action Plan also covers barriers of the circular economy, material flow, sectors of implementation, promotion of innovations and investments. In 2018 the European Union published the results and progress of circular economy implementation in the Agenda called Measuring 2018. According to the report, significant progress was noticed in the recycling of industrial and organic waste. These results prove the luck of the tools methods to measure the circular economy progress as well as its complex concept including environmental, social and economic dimensions as a single unit. In 2019 European Commission issued a new directive which is focused on circular economy goals to be reached by 2030 called "A long-term strategy for a European circular economy - setting the course for success" (European Commission, 2019a).

The concept of circular economy and the strategy of its implementation leads to the climate neutrality by investing in realistic technological solutions and aligning industrial, financial and research areas (European Commission, 2018). In 2019 European Commission has provided a report on the implementation of the Circular Economy Action Plan (European Commission, 2019b), where it has been stated, that circular economy is more tangible in comparison to other approaches that are solving the problem of sustainability in the fields of reduction of $\mathrm{CO}_{2}$ emissions, job creation, resource efficiency and productivity. At the moment European Commission is positive to continue developing goals for circular economy and issued a long-term strategic vision for 2050 called "Long-term vision for a prosperous, modern, competitive and climate neutral economy by 2050 - a clean planet for all" (European Commission, 2018). The strategic vision for 2050 highlights the resource management and prioritize environmental dimension; however, sustainable goals are being reached by eco-innovations, which require high intellectual human capital, investments, new business models and "green" consumption.

\subsection{Eco-innovations in the context of circular economy}

The circular economy includes environmental, social and economic dimensions, which interacts one with each other and can not be removed from the circular economy concept. Yearly the consumption and demand are growing, affecting the resource availability. The list of critical raw materials is continuously expanding what shows that more and more resources are getting limited. Shortage of resources would negatively impact the economy worldwide, which would lead to an unsustainable economy. Today innovative decision on recourse effective management reducing its waste is needed. The concept of the circular economy points out that it should be a closed-loop system, which means resource, as a central unit for economic development, should be used in production under "zero waste" condition. "Zero waste" approach must be implemented in all the stages of product creation: resource use, production, consumption, waste utilization and recycling - which turns waste into resources. A circular 
economy would help to maintain sustainable development and economic growth without the reducing of available resources.

Moreover circular economy would help to change production and consumption habits, business models, industries. One of the significant keys to circular economy implementation is technological development and eco-innovations. at the moment, there are plenty of barriers to implementing circular economy - economic, legal, way of thinking and perception. Still, one of the most important is technological and eco-innovative (EI) barriers. Plenty of industries/business can not turn to circular economy due to lack of technologies and eco-innovations to insure the "zero waste" approach on each stage of product life.

Eco-innovations present added value to consumers and producers with low or no impact on the environment (Makara et al., 2016). The begging of the product life-cycle and the closing the loop - are the most sensitive stages where Eco-innovations are needed to ensure the "zerowaste" approach (Figure 2).

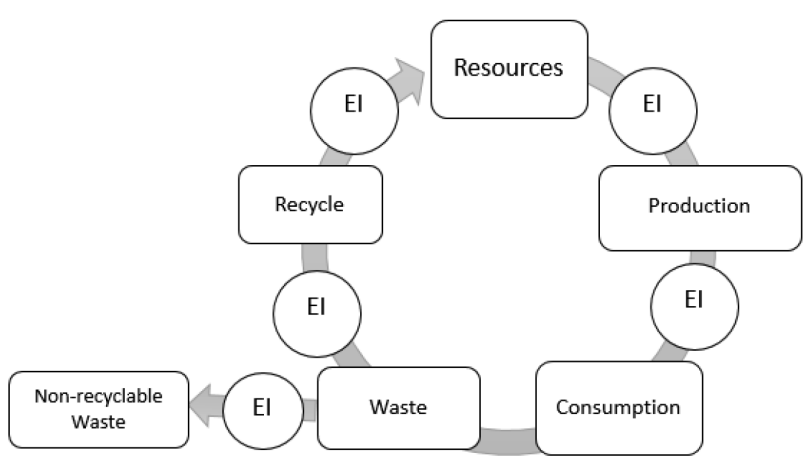

Figure 2. Eco-innovations integrated into the stages of product life-cycle in the context of circular economy (source: developed by authors)

Eco-innovations are not only making an impact on technological part of product creation or product recycling, as well influencing business models, consumption habits, market and general perception of consumers and producers towards to the saving of the environment. According to Prieto-Sandoval et al. (2018) proposed eight kinds of ecoinnovations that were being involved in circular economy:

1. Business model innovations - value creation and capture by the companies in the context of circular economy;

2. Network innovations - a symbiosis of the working groups/companies;

3. Organizational structure innovations - a new strategy to support environmentally friendly decisions;

4. Process innovations - innovations of the process of each stage of product creation and consumption;

5. Product innovations - increased quality, the functionality of the product which would satisfy customer needs and the possibility to recycle the product after the use;

6. Service innovations - increase the use of a product by making it is used several times;
7. Market innovations - consumption habits and perception of society are changing towards the circular economy approach.

Eco-innovation index measures the eco-innovation performance based on 20 indicators divided into four components: "Eco-innovation capacity", "Eco-innovation supporting snvironment", "Eco-innovation activity" and "Eco-innovation performance" (Table 1).

Table 1. Modification of Eco-Innovation Index for Circular Economy Peculiarities (source: developed by authors)

\begin{tabular}{|c|c|c|}
\hline Component & Group & Indicator \\
\hline \multirow{5}{*}{$\begin{array}{l}\text { 1. Eco- } \\
\text { innovation } \\
\text { capacity }\end{array}$} & \multirow{5}{*}{$\begin{array}{l}\text { Eco- } \\
\text { inno- } \\
\text { vation } \\
\text { index }\end{array}$} & Nation's economic competitiveness \\
\hline & & Nation's general innovation capacity \\
\hline & & $\begin{array}{l}\text { Green technology R\&D institution } \\
\text { capacity }\end{array}$ \\
\hline & & $\begin{array}{l}\text { Green technology possessed/ } \\
\text { acquired enterprises }\end{array}$ \\
\hline & & $\begin{array}{l}\text { Awareness of sustainability } \\
\text { management }\end{array}$ \\
\hline \multirow{4}{*}{$\begin{array}{l}\text { 2. Eco- } \\
\text { innovation } \\
\text { supporting } \\
\text { environment }\end{array}$} & \multirow{4}{*}{$\begin{array}{l}\text { Eco- } \\
\text { inno- } \\
\text { vation } \\
\text { index }\end{array}$} & $\begin{array}{l}\text { Government's R\&D expenditure in } \\
\text { the green industry }\end{array}$ \\
\hline & & $\begin{array}{l}\text { Implementation of environmental } \\
\text { regulations }\end{array}$ \\
\hline & & $\begin{array}{l}\text { Maturity of investment setting for } \\
\text { green technology industry }\end{array}$ \\
\hline & & $\begin{array}{l}\text { Investment scale of green } \\
\text { technology SMEs }\end{array}$ \\
\hline \multirow{5}{*}{$\begin{array}{l}\text { 3. Eco- } \\
\text { innovation } \\
\text { activities }\end{array}$} & \multirow{5}{*}{$\begin{array}{l}\text { Eco- } \\
\text { inno- } \\
\text { vation } \\
\text { index }\end{array}$} & $\begin{array}{l}\text { Commercialization level of green } \\
\text { technology }\end{array}$ \\
\hline & & $\begin{array}{l}\text { Enterprises' participation in } \\
\text { environmental management system }\end{array}$ \\
\hline & & $\begin{array}{l}\text { Economic influence of leading } \\
\text { environmentally responsive } \\
\text { enterprises }\end{array}$ \\
\hline & & Green patents \\
\hline & & $\begin{array}{l}\text { Activeness of renewable energy } \\
\text { utilization }\end{array}$ \\
\hline \multirow{6}{*}{$\begin{array}{l}\text { 4. Eco- } \\
\text { innovation } \\
\text { perfor- } \\
\text { mances }\end{array}$} & \multirow{6}{*}{$\begin{array}{l}\text { Eco- } \\
\text { inno- } \\
\text { vation } \\
\text { index }\end{array}$} & $\begin{array}{l}\text { Level of environmental impact on } \\
\text { society }\end{array}$ \\
\hline & & $\mathrm{CO}_{2}$ emission intensity \\
\hline & & Nation's energy sustainability level \\
\hline & & Water consumption intensity \\
\hline & & Jobs in green technology industry \\
\hline & & Green industry market size \\
\hline \multirow{4}{*}{$\begin{array}{l}\text { 5. Waste } \\
\text { management }\end{array}$} & \multirow{4}{*}{$\begin{array}{l}\text { Circular } \\
\text { economy } \\
\text { indi- } \\
\text { cators }\end{array}$} & Trade-in recyclable raw materials \\
\hline & & Recycling rate of municipal waste \\
\hline & & Recycling rate of e-waste \\
\hline & & Recycling of biowaste \\
\hline \multirow{6}{*}{$\begin{array}{l}\text { 6. Circular } \\
\text { economy } \\
\text { performan- } \\
\text { ces }\end{array}$} & \multirow{6}{*}{$\begin{array}{l}\text { Circular } \\
\text { economy } \\
\text { indi- } \\
\text { cators }\end{array}$} & Production-based $\mathrm{CO}_{2}$ emissions \\
\hline & & $\begin{array}{l}\text { Renewable electricity, \% total } \\
\text { electricity generation }\end{array}$ \\
\hline & & Energy intensity, TPES per capita \\
\hline & & Non-energy material productivity \\
\hline & & $\begin{array}{l}\text { Environmentally related ODA, \% } \\
\text { total ODA }\end{array}$ \\
\hline & & Circular material use rate \\
\hline
\end{tabular}


Eco-innovation capacity indicators measure innovation abilities and capacity of the country, including personnel and social components. Eco-innovation supporting environment group of indicators measures the government's institutional support for eco-innovation, the willingness of the company following eco-innovation mindset, actively participate and support a mutual relationship towards the development of eco-innovations. Eco-innovation activity group of indicators measures the implementation of eco-innovation in the corporations and usage of eco-resources in the overall economy. Ecoinnovation performance group of indicators represents the outcomes of eco-innovation activities in economic, social and environmental areas.

Eco-innovation index shows the result based on sustainable development principles based on three pillars: economic, social and environmental. However, the ecoinnovation index does not provide information regarding the main circular economy condition - zero waste. Ecoinnovation index shows the result based on the reduction of negative impact to the environment, corresponding to sustainable development. Circular economy promotes no waste and reuse of materials. For this reason, some additional indicators are being required to include the information regarding waste management and re-usage of materials.

Waste management and circular economy groups of indicators represent the generated waste, trade of recyclable materials, productivity of materials and circular material usage. These groups of indicators would help to adapt eco-innovation index to circular economy and would help to indicate eco-innovation development in the context of the circular economy. It would not show only the financial expenditure on research and development of eco-innovation, its spread among the companies and industries, support from the government side and positive environmental impact. Still, as well it would include the information on how the waste is being controlled, production-based reduction of $\mathrm{CO}_{2}$, renewable energy usage, material productivity and its ability to be recycled and reused.

\section{MCDM methods in the assessment of eco- innovation in the context of circular economy}

The circular economy is based on economic, social and environmental pillars and is a complex multidisciplinary approach supporting the sustainable development idea. Circular economy assessment is based on multiple indicators, which have different units of measurement and special requirements. Multiple-criteria decision-making methods (MCDM) are widely used in sustainability measurement of the country or region. The MCDM techniques solve problems including multiple objectives and based on ranking, priority setting, fuzzy principles and weighted averages (Strantzali \& Aravossis, 2016).

MULTIMOORA method is a multiplicative form of MOORA method, which was presented by Brauers and Zavadskas (2010). Added a multi-object optimization the updated MOORA method turned into MULTIMOORA (Stanujkic et al. 2019), which has maximizing and minimizing multiplicative functions that able to use multiple, conflicting data with different units of measurement.

MULTIMOORA is a popular method to assess many multiple objectives problems in many fields. MULTIMOORA method has been used in the implementation of EU energy policy priorities in the Baltic Sea Region (Siksnelyte et al., 2019). Also, MULTIMOORA has been used in the calculation of semi-human development index (Omrani et al., 2020), robot evaluation and selection (Liu et al., 2019a), innovative ability of universities (Dong et al., 2019) assessment of progress towards "Europe 2020" strategy targets (Fedajev et al., 2020).

Another MCDM method TOPSIS, as well as MULTIMOORA method, can solve multi-objective problems, which include different units of measurement. TOPSIS method finds out the shortest distance of the alternative to the ideal solution and ranks it as the best one (Zavadskas et al., 2016). TOPSIS method is widely used in many fields: assessing EURO 2020 strategy (Ture et al., 2019), evaluating strategies for sustainable energy planning (Solangi et al., 2019), risk assessment for sustainable engineering projects (Koulinas et al., 2019), product design concept evaluation (Tiwari et al., 2019), measuring the maturity of the carbon market in China (Liu et al., 2019b), measurement of regional green economy sustainable development ability (Wang et al., 2019).

The implementation of MULTIMOORA and TOPSIS can be divided into six major steps. The first step (Figure 3 ) includes the determination of the decision matrix.

The second step includes the normalization of selected criteria (Figure 4).

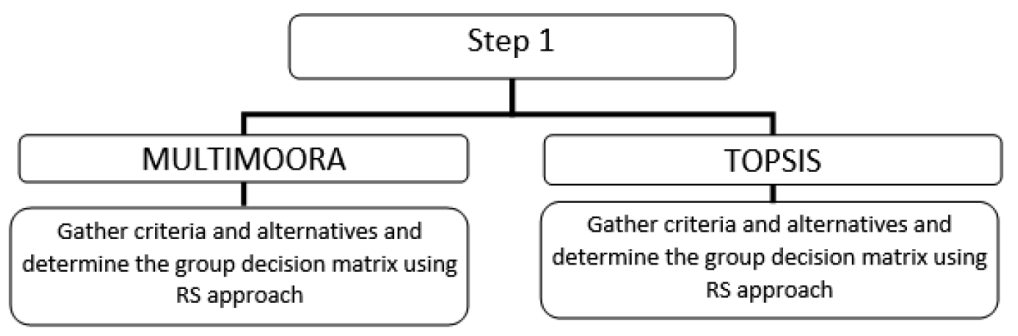

Figure 3. Decision matrix creation for TOPSIS and MULTIMOORA methods (source: developed by authors based on Brauers \& Zavadskas (2010)) 
In the third step, the values are optimized according to the need for maximization or minimization (Figure 5) using MULTIMOORA method. Using the TOPSIS method, the best and the worst possible solutions can be found out.

The fourth step finds the reference point for each criterion using MULTIMOORA and TOPSIS methods (Figure 6).

The fifth step measures the deviation of normalized values from reference point using TOPSIS and MULTIMOORA methods (Figure 7)

The last step includes final full-multiplicative form for MULTIMOORA method and relative closeness coefficient for the TOPSIS method (Figure 8).

Once the full-multiplicative form has been applied, it is possible to establish the rank of the alternatives. Once the Euclidean distance has been estimated using the TOPSIS method, the alternatives could be ranked as well. The overall ranking by using MULTIMOORA and TOPSIS methods could establish the eco-innovation development in the context of circular economy during the different periods.

\section{The assessment of eco-innovation in the context of circular economy}

In 2017 EU Strategy for the Baltic Sea Region (EUSBSR) Action plan was established by European Commission (2017) as the macro-regional strategy to save Baltic Sea by joint projects among the region. The action plan includes maintaining clear water in the sea with rich and healthy

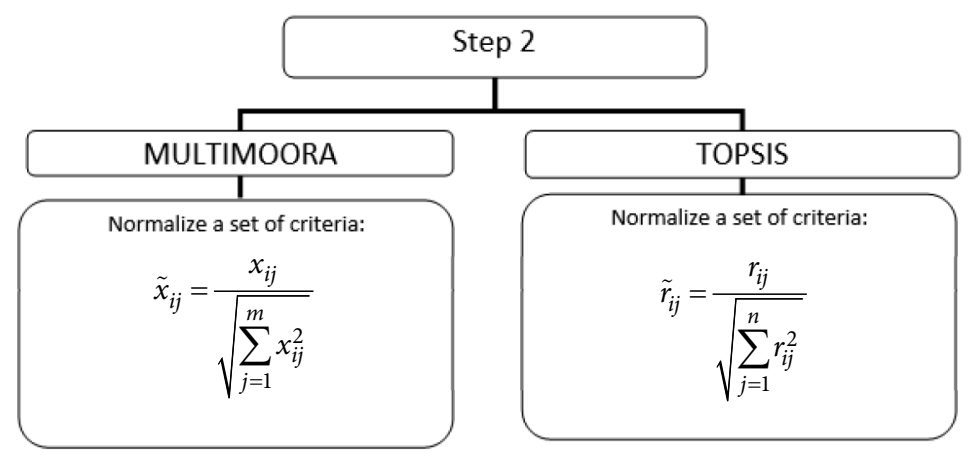

Figure 4. Normalization of the criteria by TOPSIS and MULTIMOORA methods (source: developed by authors based on Byun \& Lee (2005))

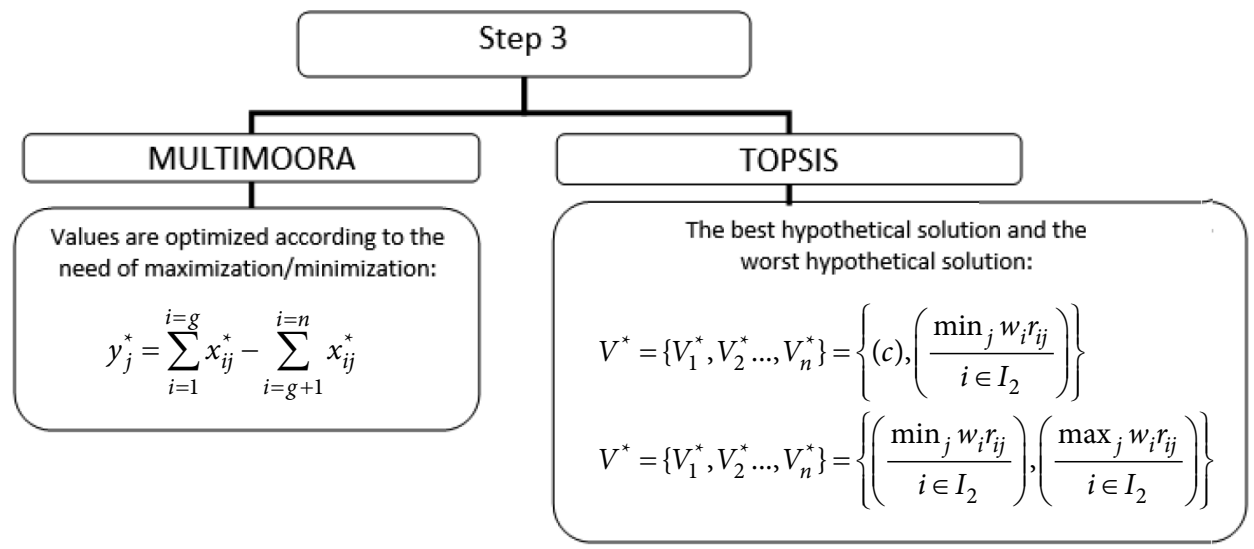

Figure 5. Maximization and minimization of criteria using TOPSIS and MULTIMOORA methods (source: developed by authors based on Brauers \& Zavadskas (2010))

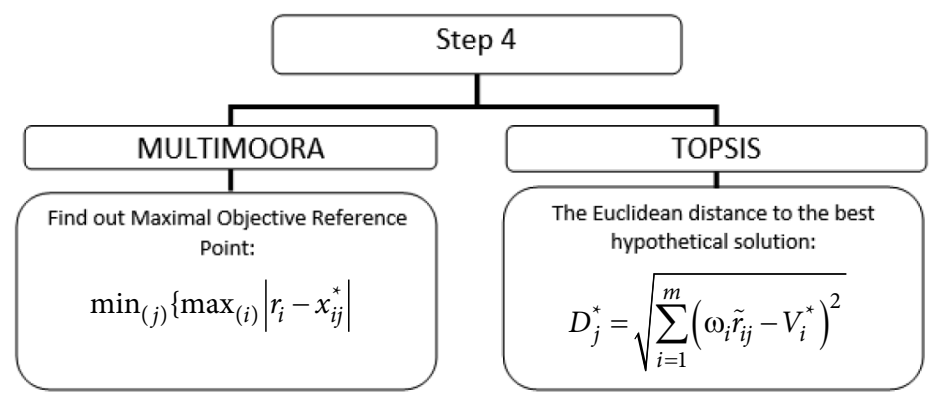

Figure 6. The reference point for each criterion using MULTIMOORA and TOPSIS methods (source: developed by authors based on Brauers \& Zavadskas (2012)) 


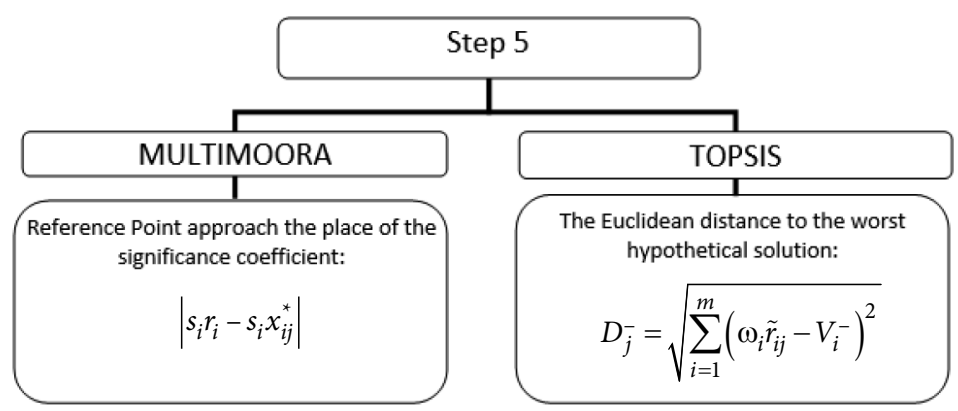

Figure 7. Deviation of normalized values using MULTIMOORA and TOPSIS methods (source: developed by authors based on Brauers \& Zavadskas (2012))

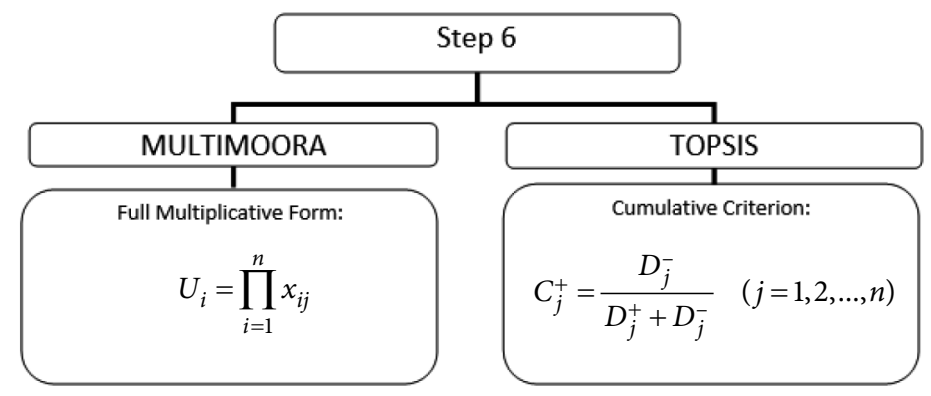

Figure 8. Full-multiplicative form for MULTIMOORA method and relative closeness coefficient for TOPSIS method (source: developed by authors based on Brauers and Zavadskas (2012))

wildlife, clean and safe shipping, improved transport conditions and single energy market creation. The creation of the Baltic Sea Region contributes to the implementation of the EUROPE 2020 strategy, what in the result would improve the competitiveness of the region. Also, as being a part of the EUROPE 2020 strategy, the Baltic Sea Region would solve ongoing issues regarding climate change. Eight countries are being included in Baltic Sea Region: Sweden, Denmark, Estonia, Finland, Germany, Latvia, Lithuania and Poland.

Data for eco-innovation aspects were collected using the following databases: European Statistical Database
- Eurostat (2020), Organization for Economic Co-Operation and Development (2020) and European Commission (2020). Data for the assessment of eco-innovation as a pillar for circular economy has been collected from 2014 to 2018 and evaluated separately by each year.

The indicators of eco-Innovations have been gathered for the Baltic Sea Region, and the data for 2014 is represented in Table 2 and Table 3. These selected data have been used for MULTIMOORA and TOPSIS methods.

In the further calculations of eco-innovation evaluation, all indicators that have included eco-innovation index has been added as the value of eco-innovation index

Table 2. Eco-innovation indicators of Sweden, Denmark, Estonia and Finland in 2014 (source: developed by authors based on Eurostat (2020), OECD (2020), European Commission (2020))

\begin{tabular}{|c|c|c|c|c|c|}
\hline & \multirow{2}{*}{ Eco-innovation indicators } & Sweden & Denmark & Estonia & Finland \\
\hline & & 2014 & 2014 & 2014 & 2014 \\
\hline Eco-innovation index & Eco-innovation index & 121.00 & 131.00 & 58.00 & 129.00 \\
\hline \multirow{4}{*}{ Waste management } & Trade in recyclable raw materials & 633341.00 & 116738.00 & 4172.00 & 32874.00 \\
\hline & Recycling rate of municipal waste & 49.30 & 43.70 & 31.30 & 32.50 \\
\hline & Recycling rate of e-waste & 52.70 & 42.30 & 30.40 & 42.40 \\
\hline & Recycling of biowaste & 72.00 & 130.00 & 17.00 & 70.00 \\
\hline \multirow{6}{*}{$\begin{array}{l}\text { Circular economy } \\
\text { performances }\end{array}$} & Production-based $\mathrm{CO}_{2}$ emissions & 71.74 & 34.44 & 17.39 & 45.71 \\
\hline & Renewable electricity, \% total electricity generation & 55.84 & 55.90 & 11.16 & 38.58 \\
\hline & Energy intensity, TPES per capita & 4.97 & 2.88 & 4.39 & 6.25 \\
\hline & Non-energy material productivity & 2.04 & 2.53 & 1.59 & 1.43 \\
\hline & Environmentally related ODA, \% total ODA & 24.71 & 33.43 & 5.24 & 23.17 \\
\hline & Circular material use rate & 6.50 & 9.10 & 11.00 & 7.30 \\
\hline
\end{tabular}


Table 3. Eco-innovation indicators of Germany, Latvia, Lithuania and Poland in 2014

(source: developed by authors based on Eurostat (2020), OECD (2020), European Commission (2020))

\begin{tabular}{|l|l|c|c|c|c|}
\hline \multirow{5}{*}{} & \multicolumn{1}{|c|}{ Eco-innovation indicators } & Germany & Latvia & Lithuania & Poland \\
\cline { 2 - 6 } & & 2014 & 2014 & 2014 & 2014 \\
\hline \multirow{5}{*}{ Eco-innovation Index } & Eco-innovation index & 135.00 & 65.00 & 66.00 & 53.00 \\
\hline \multirow{5}{*}{$\begin{array}{l}\text { Waste Management } \\
\text { Circular Economy }\end{array}$} & Trade in recyclable raw materials & 1606759.00 & 61249.00 & 31277.00 & 50044.00 \\
\cline { 2 - 6 } & Recycling rate of municipal waste & 65.60 & 27.00 & 30.50 & 26.50 \\
\cline { 2 - 6 } & Recycling rate of e-waste & 36.90 & 26.40 & 64.60 & 27.40 \\
\cline { 2 - 6 } & Recycling of biowaste & 114.00 & 13.00 & 41.00 & 15.00 \\
\hline & Production-based CO 2 emissions & 723.18 & 6.72 & 10.46 & 279.71 \\
\cline { 2 - 6 } & Renewable electricity, \% total electricity generation & 26.13 & 54.52 & 40.75 & 12.52 \\
\cline { 2 - 6 } & Energy intensity, TPES per capita & 3.76 & 2.15 & 2.35 & 2.47 \\
\cline { 2 - 6 } & Non-energy material productivity & 3.68 & 1.93 & 1.86 & 1.78 \\
\cline { 2 - 6 } & Environmentally related ODA, \% total ODA & 47.69 & 2.47 & 4.56 & 2.41 \\
\cline { 2 - 6 } & Circular material use rate & 10.70 & 5.30 & 3.80 & 12.50 \\
\hline
\end{tabular}

Table 4. Reference Point approach by MULTIMOORA method for Sweden, Denmark, Estonia and Finland in 2014 (source: developed by authors)

\begin{tabular}{|l|c|c|c|c|c|}
\hline \multirow{2}{*}{\multicolumn{1}{|c|}{ Eco-innovation indicators }} & Max/min & Sweden & Denmark & Estonia & Finland \\
\cline { 3 - 6 } & & 2014 & 2014 & 2014 & 2014 \\
\hline Eco-innovation Index & + & 0.049 & 0.014 & 0.270 & 0.021 \\
\hline Trade-in recyclable raw materials & + & 0.562 & 0.860 & 0.925 & 0.908 \\
\hline Recycling rate of municipal waste & + & 0.143 & 0.192 & 0.300 & 0.290 \\
\hline Recycling rate of e-waste & + & 0.100 & 0.187 & 0.286 & 0.186 \\
\hline Recycling of biowaste & + & 0.282 & 0.000 & 0.549 & 0.292 \\
\hline Production-based CO, emissions & - & 0.083 & 0.035 & 0.014 & 0.050 \\
\hline Renewable electricity, \% total electricity generation & + & 0.001 & 0.000 & 0.388 & 0.150 \\
\hline Energy intensity, TPES per capita & + & 0.116 & 0.305 & 0.169 & 0.000 \\
\hline Non-energy material productivity & + & 0.263 & 0.184 & 0.335 & 0.360 \\
\hline Environmentally related ODA, \% total ODA & + & 0.339 & 0.210 & 0.626 & 0.362 \\
\hline Circular material use rate & + & 0.242 & 0.137 & 0.061 & 0.210 \\
\hline
\end{tabular}

Table 5. Reference point approach by MULTIMOORA method for Germany, Latvia, Lithuania and Poland in 2014 (source: developed by authors)

\begin{tabular}{|c|c|c|c|c|c|}
\hline \multirow{2}{*}{ Eco-innovation indicators } & \multirow{2}{*}{$\mathrm{Max} / \mathrm{min}$} & Germany & Latvia & Lithuania & Poland \\
\hline & & 2014 & 2014 & 2014 & 2014 \\
\hline Eco-innovation Index & + & 0.000 & 0.245 & 0.242 & 0.287 \\
\hline Trade-in recyclable raw materials & + & 0.000 & 0.892 & 0.909 & 0.898 \\
\hline Recycling rate of municipal waste & + & 0.000 & 0.338 & 0.307 & 0.342 \\
\hline Recycling rate of e-waste & + & 0.232 & 0.320 & 0.000 & 0.311 \\
\hline Recycling of biowaste & + & 0.078 & 0.569 & 0.433 & 0.559 \\
\hline Production-based $\mathrm{CO}_{2}$ emissions & - & 0.917 & 0.000 & 0.005 & 0.349 \\
\hline Renewable electricity, \% total electricity generation & + & 0.258 & 0.012 & 0.131 & 0.376 \\
\hline Energy intensity, TPES per capita & + & 0.226 & 0.372 & 0.354 & 0.343 \\
\hline Non-energy material productivity & + & 0.000 & 0.280 & 0.291 & 0.304 \\
\hline Environmentally related ODA, \% total ODA & + & 0.000 & 0.667 & 0.636 & 0.668 \\
\hline Circular material use rate & + & 0.073 & 0.291 & 0.351 & 0.000 \\
\hline
\end{tabular}


for the country in a selected year. Waste management and circular economy performances groups of indicators have been added for evaluation of eco-innovation in the context of circular economy.

The selected criteria have been normalized using the formulas represented in Figure 3 for MULTIMOORA and TOPSIS further implementation. According to Step 3 represented in Figure 5, the values are being maximized and minimized, according to MULTIMOORA and TOPSIS methods. The deviation from reference point, which includes MULTIMOORA method, described in Step 5 (Figure 7) is represented in Table 4 and Table 5.

The Euclidean distance to the worst hypothetical solution and the best hypothetical solution provided in Step 4 (Figure 5) and Step 5 (Figure 6) were represented in Table 6 for Baltic Sea Region in 2014.

The final step 6 (Figure 7) represents a full-multiplicative form for MULTIMOORA method and relative closeness coefficient for the TOPSIS method. After step 6, the results received by MULTIMOORA (Table 7) and TOPSIS methods can be evaluated and turned as ranks of each country in the Baltic Sea Region for a selected period.
The result of eco-innovation evaluation by MULTIMOORA and TOPSIS methods for 2014 is represented in Figure 9. According to MULTIMOORA method, the highest ranks were received by Sweden, Denmark and Germany, while the lowest rank obtained by Estonia and Poland. TOPSIS result shows that the best evaluation of eco-innovation in 2014 was received by the same countries as according to MULTIMOORA method - Sweden, Germany and Denmark. The lowest rank, according to the TOPSIS method, was derived from Poland in 2014.

The result of eco-innovation evaluation by MULTIMOORA and TOPSIS methods for 2015 is represented in Figure 10. According to MULTIMOORA method, the highest ranks were attributed to Sweden, Denmark and Germany and the lowest rank attributed to Estonia. TOPSIS result shows that the best evaluation of eco-innovation in 2015 was ranked - Germany, Sweden and Denmark. The lowest rank according to the TOPSIS method, received Poland in 2015.

The result of Eco-innovation evaluation by MULTIMOORA and TOPSIS methods for 2016 is represented in Figure 11. According to MULTIMOORA method Sweden,

Table 6. Euclidean distance for Baltic Sea Region in 2014 by TOPSIS method (source: developed by authors)

\begin{tabular}{|l|c|c|c|c|c|c|c|c|}
\hline \multicolumn{1}{|c|}{ Euclidean distance } & Sweden & Denmark & Estonia & Finland & Germany & Latvia & Lithuania & Poland \\
\hline The best hypothetical solution & 0.076 & 0.091 & 0.131 & 0.106 & 0.092 & 0.133 & 0.126 & 0.139 \\
\hline The worst hypothetical solution & 0.275 & 0.302 & 0.362 & 0.325 & 0.303 & 0.365 & 0.355 & 0.373 \\
\hline
\end{tabular}

Table 7. Full-multiplicative form for Baltic Sea Region in 2014 by MULTIMOORA method (source: developed by authors)

\begin{tabular}{|l|c|c|c|c|c|c|c|c|}
\hline \multicolumn{1}{|c|}{ Full-multiplicative form } & Sweden & Denmark & Estonia & Finland & Germany & Latvia & Lithuania & Poland \\
\hline Ratio system approach & 3 & 2 & 6 & 4 & 1 & 7 & 5 & 8 \\
\hline Reference point approach & 1 & 2 & 7 & 5 & 8 & 3 & 6 & 4 \\
\hline Full multiplication & 1 & 3 & 7 & 4 & 2 & 6 & 5 & 8 \\
\hline Sum & 5 & 7 & 20 & 13 & 11 & 16 & 16 & 20 \\
\hline MULTIMOORA & 1 & 2 & $7-8$ & 4 & 3 & $5-6$ & $5-6$ & $7-8$ \\
\hline
\end{tabular}

\section{MULTIMOORA}

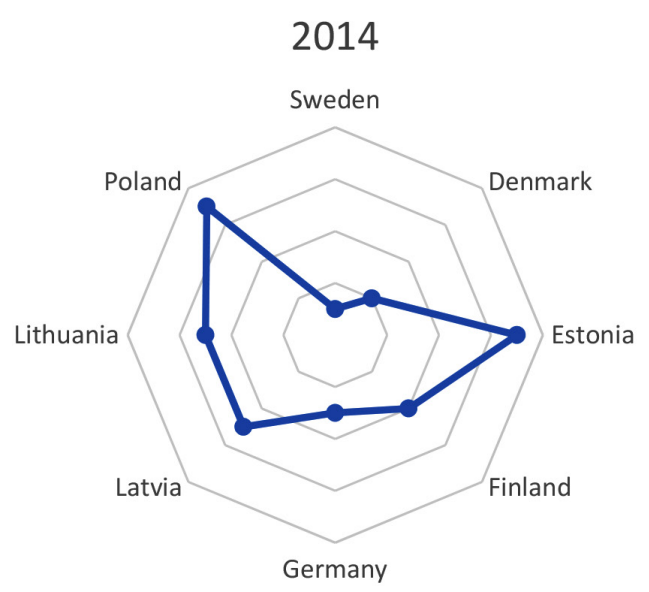

TOPSIS

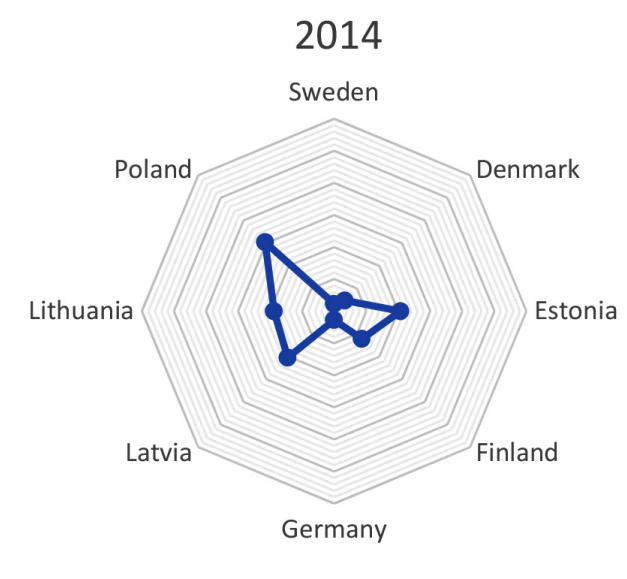

Figure 9. Eco-innovation evaluation of Baltic Sea Region in 2014 (source: developed by authors) 


\section{MULTIMOORA}

2015

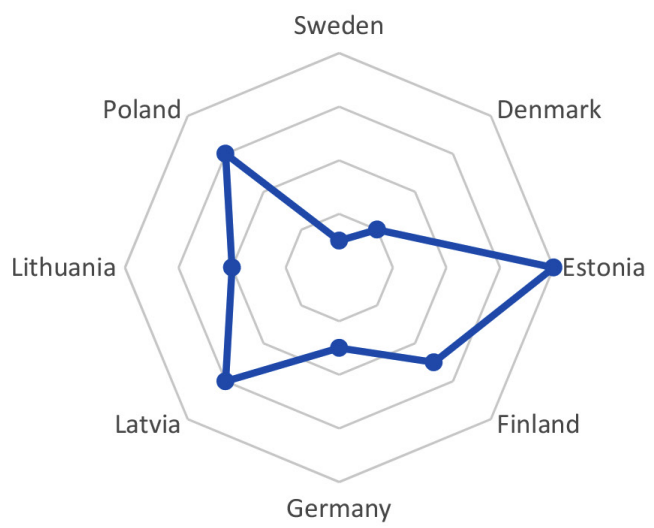

TOPSIS

2015

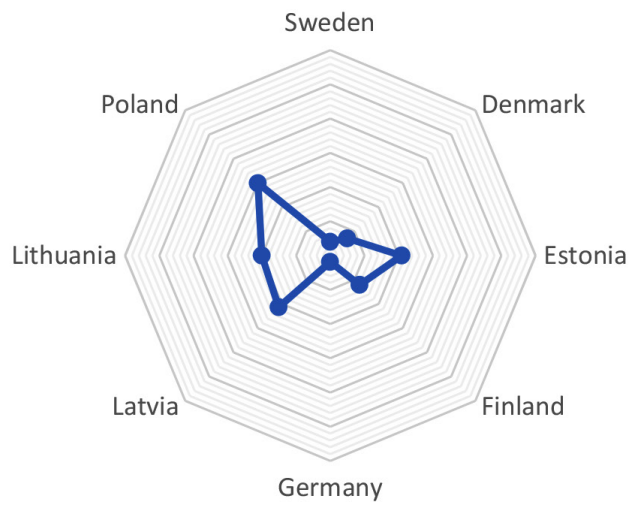

Figure 10. Eco-innovation evaluation of Baltic Sea Region in 2015 (source: developed by authors)
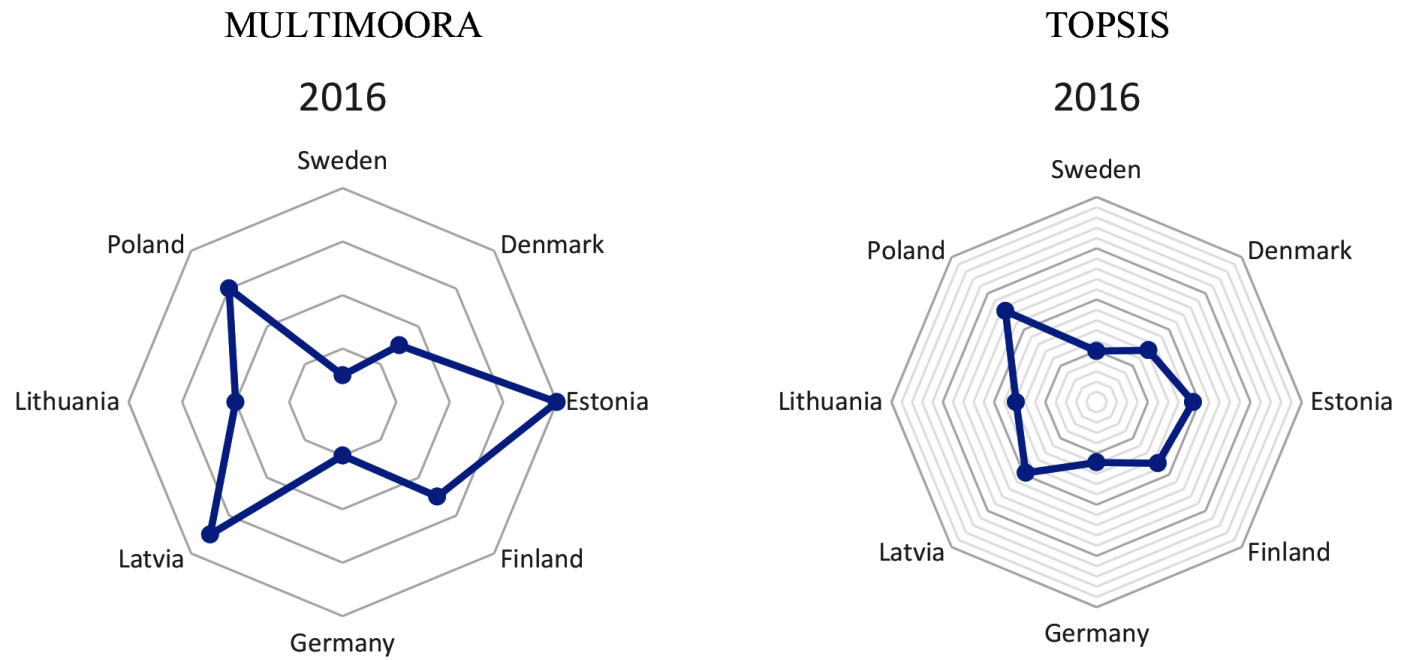

Figure 11. Eco-innovation evaluation of Baltic Sea Region in 2016 (source: made by authors)
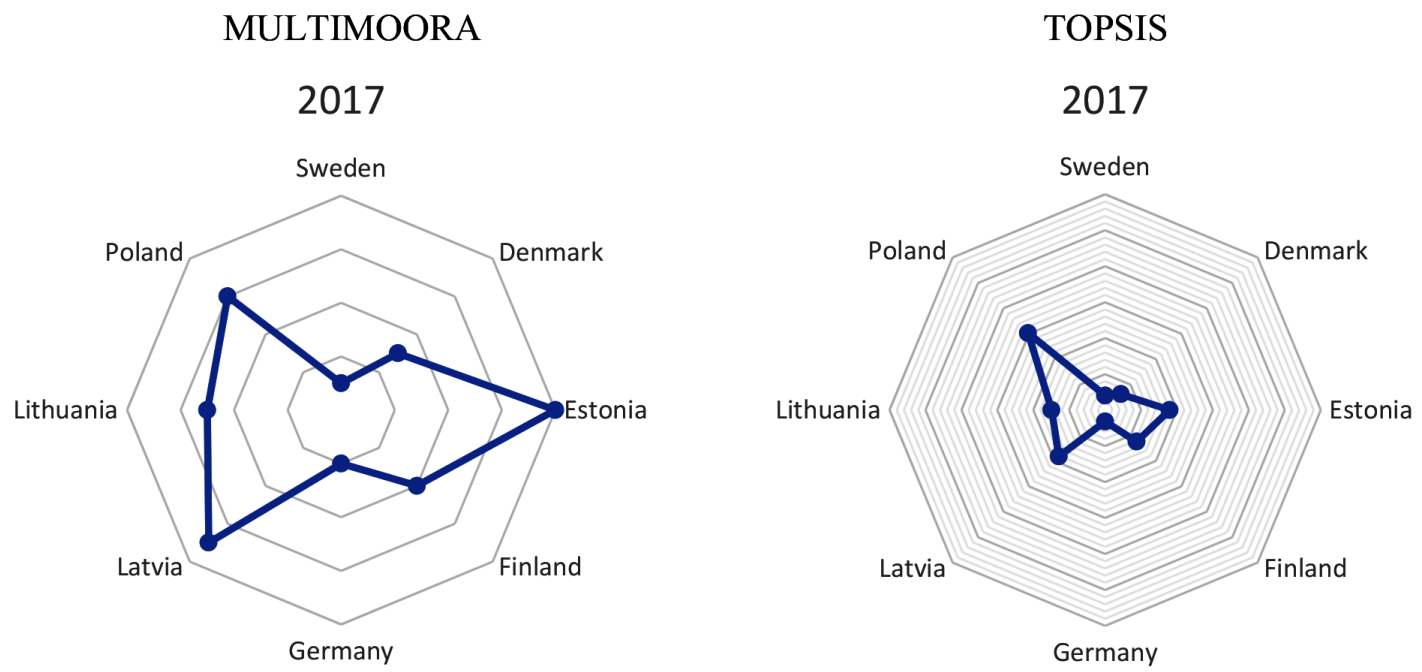

Figure 12. Eco-innovation evaluation of Baltic Sea Region in 2017 (source: made by authors) 


\section{MULTIMOORA}

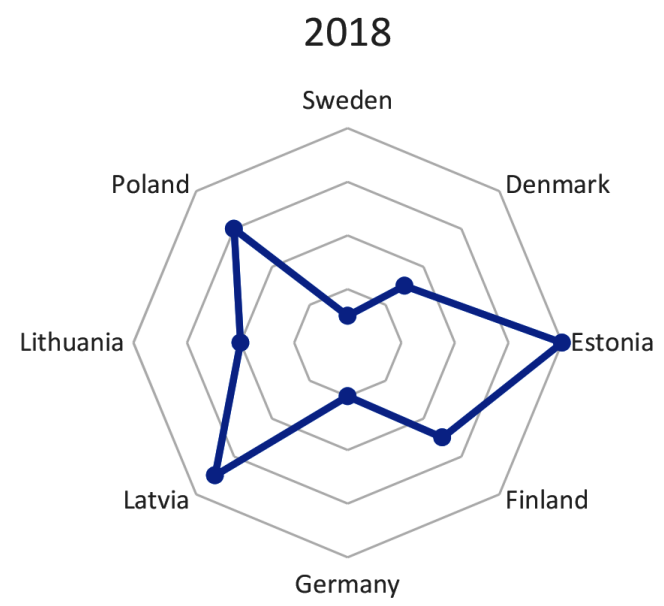

TOPSIS

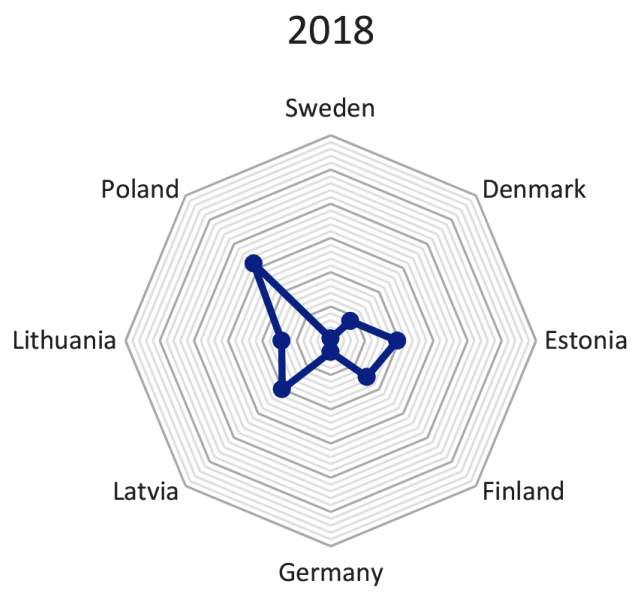

Figure 13. Eco-innovation evaluation of Baltic Sea Region in 2018 (source: made by authors)

Germany and Denmark were tagged the highest rank and Estonia the lowest rank. In respect of this, TOPSIS result shows, that the best evaluation of eco-innovation in 2016 received the same countries as according to MULTIMOORA method - Sweden, Germany and Denmark. The lowest rank according to the TOPSIS method, received Poland in 2016 therein.

The result of eco-innovation evaluation by MULTIMOORA and TOPSIS methods for 2017 is represented in Figure 12. According to MULTIMOORA method, the highest rank received was that of Sweden, Germany and Denmark, and the lowest rank received belongs to Estonia. TOPSIS result shows that the best evaluation of Ecoinnovation in 2017 received was that of Germany, Sweden and Denmark. The lowest rank, according to the TOPSIS method received was that of Poland in 2017.

The result of eco-innovation evaluation by MULTIMOORA and TOPSIS methods for 2018 is represented in Figure 13. According to MULTIMOORA method, the highest rank received was that of Sweden, Germany and Denmark, and the lowest rank received belongs to Estonia. TOPSIS result shows that the best evaluation of ecoinnovation in 2017 received was that of Sweden, Germany and Denmark. The lowest rank, according to the TOPSIS method received was that of Poland in 2018.

The development of eco-innovation in the Baltic Sea Region in the context of circular economy during the period of 2014-2018, according to MULTIMOORA is represented in Figure 13. Sweden was in the leading position in the development of eco-innovation, moreover, at the end of 2018, Sweden has strengthened its position to be a leader among all the countries in the Baltic Sea Region. According to eco-innovation index from 2014 to 2018 Sweden was remaining one of the leaders and grew up by 2018. Denmark remains in the same position according to MULTIMOORA results in the period of 2014-2018. However, the value of eco-innovation index has decreased by 2018 . Germany holds the second position after Sweden according to MULTIMOORA and is one of the most influential countries in the development of eco-innovation by the index. In addition to this, by 2018, Germany has increased the result according to MULTIMOORA, but the index remains the same during the period. Finland, according to MULTIMOORA, is fourth out of eight countries. However, the index shows Finland in the leaders during 2014-2018. Estonia, Latvia, Lithuania and Poland according to MULTIMOORA and index, have been evaluated by the lowest ranks. However, although the index is lower than Sweden, Germany, Denmark and Finland, it shows that Estonia, Latvia and Lithuania developed ecoinnovation index by 2018.

The development of eco-innovation in Baltic Sea Region in the context of Circular Economy during the period of 2014-2018, according to TOPSIS is represented in Figure 14. According to TOPSIS results Sweden, Denmark and Germany are in the leading position as well as according to the Eco-innovation index. According to TOPSIS and Eco-innovation index, Sweden has increased the result by 2018, and Denmark has decreased the result by 2018.

Finland holds fourth position, and it corresponds to the result of MULTIMOORA. Estonia, Latvia, Lithuania and Poland were evaluated with the lowest rank, which corresponds to the result of the index. Lithuania, according to TOPSIS and eco-innovation index has increased the result by 2018. TOPSIS as MULTIMOORA has ranked same countries by highest rank, Finland and Lithuania have scored by middle-rank and Estonia, Latvia Poland has scored by the lowest rank. The development of ecoinnovation index in the Baltic Sea Region and the development of eco-innovation in the context of circular economy is represented in Figure 15. According to the data represented, it is possible to see the tendency of growing or decreasing of eco-innovation index itself and eco-innovation in the context of circular economy. The represented data is already ranked according to MULTIMOORA 


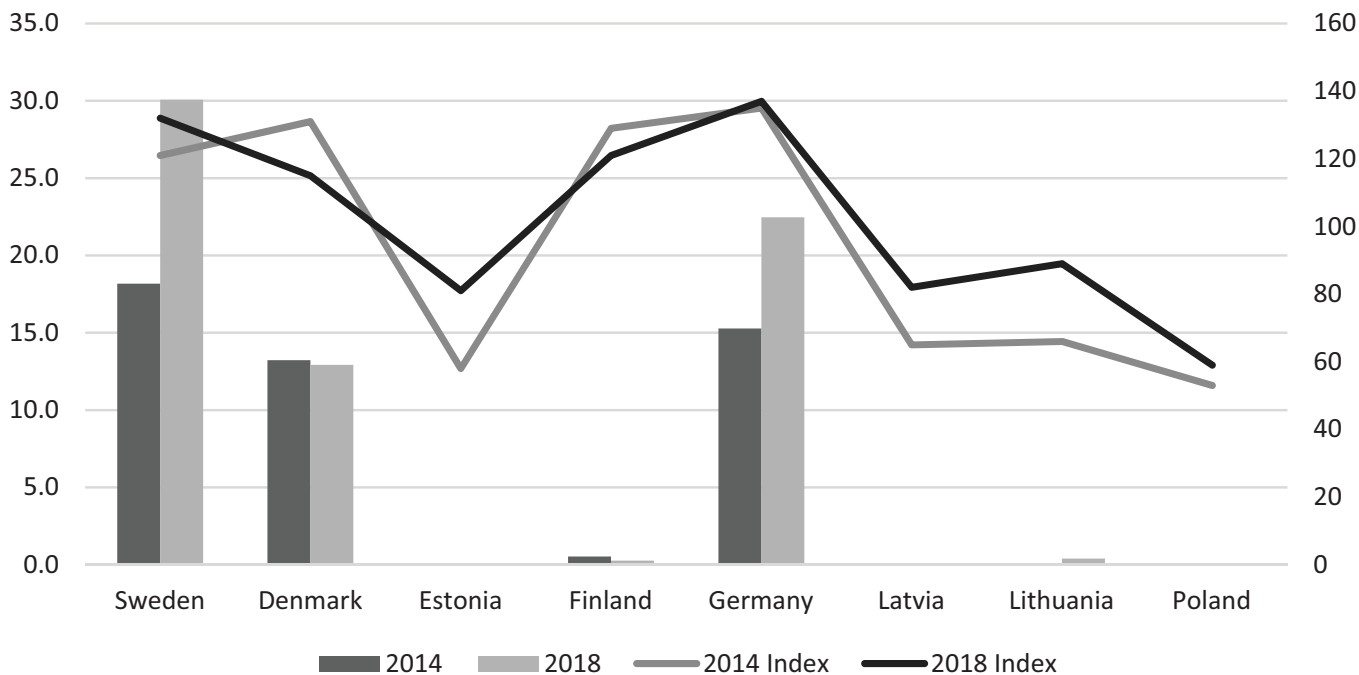

Figure 14. Development of eco-innovation in Baltic Sea Region in the period of 2014-2018 represented by MULTIMOORA and eco-innovation index (source: developed by authors)

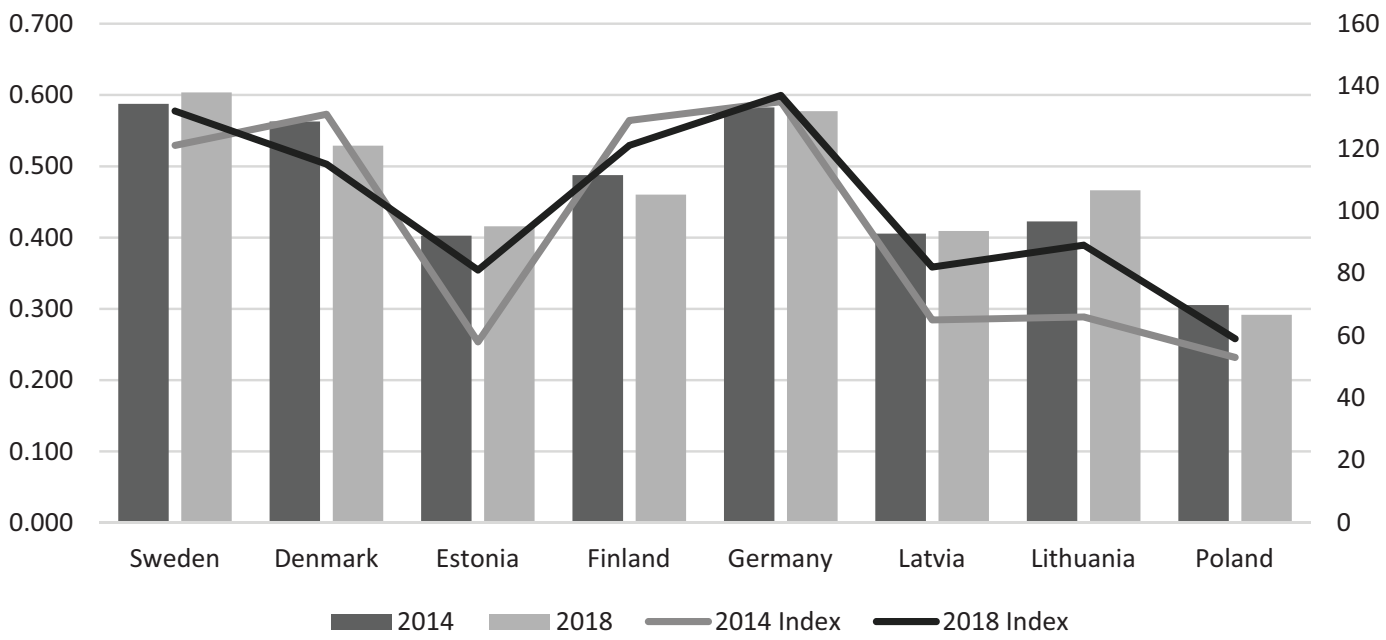

Figure 15. Development of eco-innovation in Baltic Sea Region in the period of 2014-2018 represented by TOPSIS and eco-innovation index (source: developed by authors)

and TOPSIS. The value of eco-innovation index has been ranked according to the values of the index. The gradient shows the ranked position of the selected country by the year - the darker font means lower rank the country owes, and opposite, the lighter font - the higher position holds the country.

For example, Finland has been evaluated by MULTIMOORA and TOPSIS with the rank 4-5 from 2014 to 2018, what is the middle position, however, eco-innovation index has been ranked $3^{\text {rd }}$, what is one of the leading positions.

To sum up, eco-innovation index (Table 8) shows the development of eco-innovation responding to the goal of sustainable development, however, modified eco-innovation index counts in the specification of circular economy and based on the additional circular economy indicators the result of eco-innovation varies in comparison to ecoinnovation index. TOPSIS and MULTIMOORA methods identified the leading countries in the development of eco-innovation in the context of circular economy, which are Sweden, Denmark and Germany. Also, according to

Table 8. Development of eco-innovation index and ecoinnovation as a pillar of circular economy assessed using MULTIMOORA and TOPSIS methods in the Baltic Sea Region in 2014-2018 (source: developed by authors)

\begin{tabular}{|c|c|c|c|c|c|c|}
\hline & \multicolumn{2}{|c|}{ MULTIMORA } & \multicolumn{2}{|c|}{ TOPSIS } & \multicolumn{2}{|c|}{ Index } \\
\hline & 2014 & 2018 & 2014 & 2018 & 2014 & 2018 \\
\hline Sweden & $\downarrow 1$ & $\downarrow 1$ & $\downarrow 1$ & $\downarrow 1$ & $\rightarrow 4$ & $\downarrow 2$ \\
\hline Denmark & $\downarrow 2$ & $\downarrow 3$ & $\downarrow 3$ & $\downarrow 3$ & $\downarrow 2$ & $\rightarrow 4$ \\
\hline Estonia & $\uparrow 7$ & $\uparrow 8$ & $\uparrow 7$ & $\uparrow 6$ & $\uparrow 7$ & $\uparrow 7$ \\
\hline Finland & $\rightarrow 4$ & $\rightarrow 5$ & $\rightarrow 4$ & $\rightarrow 5$ & $\downarrow 3$ & $\downarrow 3$ \\
\hline Germany & $\downarrow 3$ & $\downarrow 2$ & $\downarrow 2$ & $\downarrow 2$ & $\downarrow 1$ & $\downarrow 1$ \\
\hline Latvia & $\rightarrow 5$ & $\uparrow 7$ & $\uparrow 6$ & $\uparrow 7$ & $\uparrow 6$ & $\uparrow 6$ \\
\hline Lithuania & $\rightarrow 5$ & $\rightarrow 4$ & $\rightarrow 5$ & $\rightarrow 4$ & $\rightarrow 5$ & $\rightarrow 5$ \\
\hline Poland & $\uparrow 7$ & $\uparrow 6$ & $\uparrow 8$ & $\uparrow 8$ & $\uparrow 8$ & $\uparrow 8$ \\
\hline
\end{tabular}


TOPSIS and MULTIMOORA methods, the lowest ranks got countries: Latvia, Estonia and Poland. Finland and Lithuania have been ranked in the middle by MULTIMOORA and TOPSIS methods.

\section{Conclusions}

The circular economy is quite a new economic approach which aims to eliminate the waste until zero from every production or consumption step, promotes recycling and secondary usage of the materials, in the same way, maintain economic development. the circular economy includes environmental, economic and social pillars aligned with the sustainability approach. Circular economy ensures sustainable development as is aligned with Sustainable Development Goals. However, there are many barriers to switch from linear economy model to circular economy: technological, legal, economic, social barriers.

Eco-innovation could help to switch from linear economy to circular economy more quickly and efficiently. Today the total shift to circular economy is impossible as a zero-waste approach would not be ensured, but with the development of technologies and eco-innovation step by step circular economy approach can be partially implemented. At the moment there is a huge need of eco-innovations - new business model innovation that would be concordant with circular economy approach, network innovations that would create a symbiosis of the working groups supporting the idea of circular economy, process and product innovation, service and market innovation that would change consumption habits towards the concept of circular economy.

Eco-innovation has been analyzed in the Baltic Sea Region from 2014 to 2018 using MULTIMOORAand TOPSIS methods. As well, based on the circular economy specification eco-innovation index, that is used to assess the eco-innovation worldwide, has been modified to measure eco-innovation in the context of circular economy. Moreover, the development of eco-innovation in the context of circular economy has been analyzed from 2014 to 2018 and compared to the eco-innovation index.

The results of MULTIMOORA and TOPSIS methods show the same evaluation of eco-innovation development in the context of circular economy as e research shows the best development of eco-innovation show Sweden, Denmark and Germany. Finland and Lithuania have been middle-ranked by MULTIMOORA and TOPSIS. Lowest ranks got Latvia, Estonia and Poland using MULTIMOORA and TOPSIS methods.

Eco-innovation assessment in the context of circular economy differs by the comparison to eco-innovation index. Additional circular economy indicators assess ecoinnovation including circular economy aspects such as zero waste, efficient resources use, recycling and reuse of materials.

\section{References}

Brauers, W. K. M., \& Zavadskas, E. K. (2010). Robustness in the MULTIMOORA model: the example of Tanzania. Transformations in Business and Economics, 9(3), 67-83.

Brauers, W. K. M., \& Zavadskas E. K. (2012). Robustness of MULTIMOORA: a method for multi-objective optimization. Informatica, 23, 1-25.

https://doi.org/10.15388/Informatica.2012.346

Busu, C., \& Busu, M. (2018). Modelling the Circular Economy Processes at the EU level using an evaluation algorithm based on Shannon entropy. Processes, 6(11), 225.

https://doi.org/10.3390/pr6110225

Byun, H. S., \& Lee, K. H. (2005). A decision support system for the selection of a rapid prototyping process using the modified TOPSIS method. International Journal of Advanced Manufacturing Technology, 26, 1338-1347.

https://doi.org/10.1007/s00170-004-2099-2

De Almeida, S. T., \& Borsato, M. (2019). Assessing the efficiency of end of life technology in waste treatment - a bibliometric literature review. Resources Conservation and Recycling, 140, 189-208. https://doi.org/10.1016/j.resconrec.2018.09.020

Dong, L., Gu, X., \& Wu, X. (2019). An improved MULTIMOORA method with combined weights and its application in assessing the innovative ability of universities. Expert Systems 36(2), e12362. https://doi.org/10.1111/exsy.12362

European Commission. (2010). Strategy "EUROPE 2020". https://ec.europa.eu/eu2020/pdf/COMPLET\%20EN\%20 BARROSO\%20\%20\%20007\%20-\%20Europe\%202020\%20 -\%20EN\%20version.pdf

European Commission. (2013). Environment Action Programme. https://ec.europa.eu/environment/action-programme/

European Commission. (2015). Circular Economy Action Plan. https://ec.europa.eu/environment/circular-economy/

European Commission. (2017). European Union Strategy for the Baltic Sea Region. Action plan. https://www.balticsea-regionstrategy.eu/action-plan/17-action-plan-2015/download

European Commission. (2018). Programme "Innovation Union". https://ec.europa.eu/info/research-and-innovation/strategy/ goals-research-and-innovation-policy/innovation-union_lt

European Commission. (2019a). A long-term strategy for a European Circular Economy - setting the course for success.

https://circulareconomy.europa.eu/platform/en/knowledge/ long-term-strategy-european-circular-economy-settingcourse-success

European Commission. (2019b). Report on the Implementation of the Circular Economy Action Plan (Communication from the Commission to the European Parliament, the Council, the European Economic and Social Committee and the Committee of the Regions). https://eurlex.europa.eu/legalcontent/EN/ TXT/?uri=CELEX\%3A52019DC0190

European Commission. (2020). Eco-Innovation Index. https:// ec.europa.eu/environment/ecoap/indicators/index_en

European Environment Agency. (2018). Programme "Innovation Union". https://www.eea.europa.eu/policy-documents/aresource-efficient-europe

Eurostat. (2020). Sustainable development indicators. https://ec.europa.eu/eurostat/web/sdi/indicators

Fedajev, A., Stanujkic, D., Karabasevic, D., Brauers, W. K. M., \& Zavadskas, E. K. (2020). Assessment of progress towards "Europe 2020" strategy targets by using the MULTIMOORA method and the Shannon Entropy Index. Journal of Cleaner Production, 244, 118895.

https://doi.org/10.1016/j.jclepro.2019.118895 
Grigoryan, A. A., \& Borodavkina, N. Y. (2017). The Baltics on their way towards a circular economy. Baltic Region, 9(3), 4-14. https://doi.org/10.5922/2079-8555-2017-3-1

High-Level Political Forum On Sustainable Development. (2012). 10-Year Framework of Programmes on Sustainable Consumption and Production Patterns. https://sustainabledevelopment. un.org/content/documents/1444HLPF_10YFP2.pdf

Hroncova Vicianova, J., Jad’ud’ová, J., Hronec, M., \& Rolíková, S. (2017). Developing eco-innovation in business practice in Slovakia. Journal of Business Economics and Management, 18(5), 1042-1061. https://doi.org/10.3846/16111699.2017.1381146

Koulinas, G. K., Demesouka, O. E., Marhavilas, P. K., Vavatsikos A. P., \& Koulouriotis, D. E. (2019). Risk assessment using Fuzzy TOPSIS and PRAT for sustainable engineering projects. Sustainability, 11(3), 615.

https://doi.org/10.3390/su11030615

Lahti, T., Wincent, J., \& Parida, V. (2018). A definition and theoretical review of the circular economy, value creation, and sustainable business models: where are we now and where should research move in the future? Sustainability, 10, 2799. https://doi.org/10.3390/su10082799

Liu, H., Zhao, H., You, X., \& Zhou, W. (2019a). Robot evaluation and selection using the Hesitant Fuzzy Linguistic MULTIMOORA method. Journal of Testing and Evaluation, 47(2), 1405-1426. https://doi.org/10.1520/JTE20170094

Liu, X., Zhou, X., Zhu, B., He, K., \& Wang, P. (2019b). Measuring the maturity of carbon market in China: an entropybased TOPSIS approach. Journal of Cleaner Production, 229, 94-103. https://doi.org/10.1016/j.jclepro.2019.04.380

Makara, A., Smol, M., Kulczycka, J., \& Kowalski, Z. (2016). Technological, environmental and economic assessment of sodium tripolyphosphate production-a case study. Journal of Clean Production, 133, 243-251.

https://doi.org/10.1016/j.jclepro.2016.05.096

Measuring. (2018). Measuring progress towards circular economy in the European Union - Key indicators for a monitoring framework. http://ec.europa.eu/environment/circular-economy/pdf/monitoringframework_staff-working-document.pdf

Omrani, H., Alizadeh, A., \& Amini, M. (2020). A new approach based on BWM and MULTIMOORA methods for calculating semi-human development index: An application for provinces of Iran. Socio-Economic Planning Sciences, 70. https://doi.org/10.1016/j.seps.2019.02.004

Organization for Economic Co-Operation and Development (OECD). (2020). Green growth indicators. http://stats.oecd. org/Index.aspx? DataSetCode=GREEN_GROWTH\#

Prieto-Sandoval, V., Jaca, C., \& Ormazabal, M. (2018). Towards a consensus on the Circular Economy. Journal of Clean Production, 179, 605-615.

https://doi.org/10.1016/j.jclepro.2017.12.224

Saraiva, A. B., Souza, R. G., Mahler C. F., \& Valle, R. A. B. (2018). Consequentiale life-cycle modelling of solid waste management systems - Reviewing choices and exploring their conse- quences. Journal of Clean Production, 202, 488-496. https://doi.org/10.1016/j.jclepro.2018.08.038

Shafique, M., Asghar, M., \& Rahman, H. (2017). The impact of green supply chain management practices on performance: Moderating role of institutional pressure with mediating effect of green innovation. Business, Management and Education, 15(1), 91-108. https://doi.org/10.3846/bme.2017.354

Siksnelyte, I., Zavadskas, E. K., Bausys, R., \& Streimikiene, D. (2019). Implementation of EU energy policy priorities in the Baltic Sea Region countries: Sustainability assessment based on neutrosophic MULTIMOORA method. Energy Policy, 125, 90-102. https://doi.org/10.1016/j.enpol.2018.10.013

Solangi, Y. A., Tan, Q., Mirjat, N. H., \& Ali, S. (2019). Evaluating the strategies for sustainable energy planning in Pakistan: An integrated SWOT-AHP and Fuzzy-TOPSIS approach. Journal of Cleaner Production, 236. https://doi.org/10.1016/j.jclepro.2019.117655

Stanujkic, D., Karabasevic, D., Zavadskas, E. K., Smarandache, F., \& Brauers, W. K. (2019). A bipolar fuzzy extension of the MULTIMOORA method. Informatica, 30(1), 135-152. https://doi.org/10.15388/Informatica.2019.201

Strantzali, E., \& Aravossis, K. (2016). Decision making in renewable energy investments: a review. Renewable and Sustainable Energy reviews, 55, 885-989.

https://doi.org/10.1016/j.rser.2015.11.021

Tiwari, V., Jain, P. K., \& Tandon, P. (2019). An integrated Shannon entropy and TOPSIS for product design concept evaluation based on bijective soft set. Journal of Intelligent Manufacturing, 30, 1645-1658. https://doi.org/10.1007/s10845-017-1346-y

Tseng, M. L., Wong, W. P., \& Soh, K. L. (2018). An overview of the substance of resource, conservation and recycling. Resources Conservation and Recycling, 136, 367-375. https://doi.org/10.1016/j.resconrec.2018.05.010

Ture, H., Dogan, S., \& Kocak, D. (2019). Assessing EURO 2020 Strategy Using Multicriteria Decision Making Methods: VIKOR and TOPSIS. Social Indicators Research, 142, 645665. https://doi.org/10.1007/s11205-018-1938-8

UN. (2015). UN Agenda for Sustainable Development. https://sustainabledevelopment.un.org/post2015/transformingourworld

Wang, M., Zhao, X., Gong, Q., \& Ji, Z. (2019). Measurement of Regional Green Economy sustainable development ability based on Entropy Weight-Topsis-Coupling Coordination Degree - A case study in Shandong Province, China. Sustainability, 11(1), 280. https://doi.org/10.3390/su11010280

WCED. (1987). Report of the World Commission on Environment and Development: Our Common Future. Oxford University Press, 43.

Zavadskas, E. K., Mardani, A., Turskis, Z., Jusoh, A., \& MD Nor, K. (2016). Development of TOPSIS method to solve complicated decision-making problems: an overview on developments from 2000 to 2015. International Journal of Information Technology \& Decision Making, 15, 1-37. https://doi.org/10.1142/S0219622016300019 